J. Dairy Sci. 95:3609-3616

http://dx.doi.org/10.3168/jds.2011-5285

(C) American Dairy Science Association ${ }^{\circledR}, 2012$.

\title{
Application of salt whey in process cheese food made from Cheddar cheese containing exopolysaccharides
}

\author{
O. Janevski, ${ }^{1}$ A. N. Hassan, ${ }^{2}$ and L. Metzger \\ Dairy Science Department, South Dakota State University, Brookings 57007
}

\begin{abstract}
The objective of this work was to use salt whey in making process cheese food (PCF) from young (3-wkold) Cheddar cheese. To maximize the level of salt whey in process cheese, low salt $(0.6 \%)$ Cheddar cheese was used. Because salt reduction causes undesirable physiochemical changes during extended cheese ripening, young Cheddar cheese was used in making process cheese. An exopolysaccharide (EPS)-producing strain (JFR) and a non-EPS-producing culture (DVS) were applied in making Cheddar cheese. To obtain similar composition and $\mathrm{pH}$ in the EPS-positive and EPSnegative Cheddar cheeses, the cheese making protocol was modified in the latter cheese to increase its moisture content. No differences were seen in the proteolysis between EPS-positive and EPS-negative Cheddar cheeses. Cheddar cheese made with the EPS-producing strain was softer, and less gummy and chewy than that made with the EPS-negative culture. Three-week-old Cheddar cheese was shredded and stored frozen until used for PCF manufacture. Composition of Cheddar cheese was determined and used to formulate the corresponding PCF (EPS-positive PCF and EPS-negative PCF). The utilization of low salt Cheddar cheese allowed up to $13 \%$ of salt whey containing $9.1 \%$ salt to be used in process cheese making. The preblend was mixed in the rapid visco analyzer at 1,000 rpm and heated at $95^{\circ} \mathrm{C}$ for $3 \mathrm{~min}$; then, the process cheese was transferred into copper cylinders, sealed, and kept at $4^{\circ} \mathrm{C}$. Process cheese foods contained $43.28 \%$ moisture, $23.7 \%$ fat, $18.9 \%$ protein, and $2 \%$ salt. No difference in composition was seen between the EPS-positive and EPS-negative PCF. The texture profile analysis showed that EPS-positive PCF was softer, and less gummy and chewy than EPS-negative PCF. The end apparent viscosity and meltability were higher in EPS-positive PCF than in EPS-negative PCF, whereas emulsification time was shorter in the former cheese. Sensory
\end{abstract}

\footnotetext{
Received December 21, 2011.

Accepted March 6, 2012.

${ }^{1}$ Current address: Leprino Foods, Allendale, MI 49401.

${ }^{2}$ Corresponding author: Ashraf.Hassan@sdstate.edu
}

evaluation indicated that salt whey at the level used in this study did not affect cheese flavor. In conclusion, process cheese, containing almost $13 \%$ salt whey, with improved textural and melting properties could be made from young EPS-positive Cheddar cheese.

Key words: salt whey, process cheese, exopolysaccharide, texture

\section{INTRODUCTION}

The amount of whey produced in the world increases every day. In the past $20 \mathrm{yr}$, different methods and technologies have been developed to utilize whey and reduce or eliminate the amount disposed in the environment. Salt whey is a product obtained during the manufacture of cheeses such as Cheddar. A smaller portion (20 to $40 \%$ ) of this whey is obtained during the mellowing stage, whereas the large part (60 to 80\%) is collected during draining and pressing (Sutherland, 1974). Salt whey, unlike the sweet type, cannot be conveniently processed because of its high salinity and high biological and chemical oxygen demand (Zayed and Winter, 1995; Sanderson at al., 1996). The latest proposed application of salt whey is its utilization as an ingredient in process cheese (Kapoor and Metzger, 2004). In addition to salt and water, salt whey contains whey proteins and lactose that could alter the quality of process cheese. Up to $2.2 \%$ whey protein can be incorporated into process cheese without affecting its quality (Gupta and Reuter, 1992). When lactose content exceeds $17 \%$ in the aqueous phase it forms crystals (Thomas, 1973; Zehren and Nusbaum, 2000). A maximum of $7.6 \%$ of a process cheese food formula (water and salt) could be replaced with salt whey in previous studies (Kapoor and Metzger, 2004).

One of the important factors affecting process cheese functionality is the level of intact casein in the base cheese. Purna et al. (2006) manufactured process cheese using the same natural cheese at different ages and concluded that a reduction in intact casein in natural cheese led to decreased viscosity and firmness and increased meltability of process cheese made using it. The objective of this study was to maximize the level of salt whey that can be used in process cheese. To achieve 
this objective, low salt Cheddar cheese was used in the formulation. Low salt in Cheddar cheese causes undesirable physiochemical changes during extended ripening (Thakur et al., 1975). Therefore, young low salt cheese was utilized in this study. The young cheese, however, contains high levels of intact casein and is hard to melt. Exopolysaccharide (EPS)-producing cultures can be used to enhance the melting properties of cheese (Awad et al., 2005). When produced by starter cultures, EPS interfere with protein-protein interactions in cheese and can contribute to changes in its texture, melting, and viscoelastic properties (Hassan, 2008). Therefore, this study was designed to use 3-wk-old EPS-positive Cheddar cheese and salt whey in making process cheese food (PCF).

\section{MATERIALS AND METHODS}

\section{Cultures}

Bulk starter cultures were used from both EPS-producing and nonproducing cultures. The nonproducing culture was a frozen culture (DVS 850) supplied by Chr. Hansen (Milwaukee, WI). Approximately $0.023 \%$ of the frozen culture was propagated in steamed skim milk $\left(95^{\circ} \mathrm{C}\right.$ for $\left.45 \mathrm{~min}\right)$, and incubated at $32^{\circ} \mathrm{C}$ for 10 to 12 $\mathrm{h}$ to give the bulk starter culture. The EPS-producing culture used in this study was a ropy strain of Lactococcus lactis ssp. cremoris (JFR; Hassan et al., 2003; Ayala-Hernández et al., 2008). The stock culture of JFR was maintained at $-80^{\circ} \mathrm{C}$. One bead of the stock culture was incubated for 10 to $12 \mathrm{~h}$ at $32^{\circ} \mathrm{C}$ in $10 \mathrm{~mL}$ of M17 broth (Becton Dickinson and Co., Sparks, MD) supplemented with lactose (0.5\%; Oxoid Ltd., Basingstoke, UK). The culture was then transferred $(1 \% \mathrm{vol} /$ vol) to steamed skim milk and incubated at $32^{\circ} \mathrm{C}$ for 10 to $12 \mathrm{~h}$. Final transfer $(1 \% \mathrm{vol} / \mathrm{vol})$ was made to steamed milk, which was then incubated for 10 to 12 $\mathrm{h}$ to give the bulk starter culture. After incubation, both bulk starter cultures were cooled to refrigeration temperature for $4 \mathrm{~h}$.

\section{Milk and Salt Whey}

Raw milk was obtained from the Dairy Research and Training Facility at South Dakota State University (Brookings). Milk was separated (model \#392, Separators Inc., Indianapolis, IN) to cream and skim milk. The fat and casein levels were determined using the casein/fat Standardizer-CFS (Metron Instruments Inc., Cleveland, $\mathrm{OH}$ ), and cheese milk was adjusted to $3.4 \%$ milk fat, which maintained a casein:fat ratio of approximately 0.74 . The standardized cheese raw milk was kept at 4 to $5^{\circ} \mathrm{C}$ until cheese manufacture (same or next day).

Salt whey was obtained from Bongards' Creameries (Bongards, MN). Whey was pasteurized at $63^{\circ} \mathrm{C}$ for 30 min in a steam chest (Meyer-Blanke Co., St. Louis, $\mathrm{MO}$ ) and stored frozen until used in PCF manufacture.

\section{Cheddar Cheese Making}

Milk was standardized to $3.4 \%$ fat, pasteurized at $63^{\circ} \mathrm{C}$ for $30 \mathrm{~min}$, and cooled to less than $15^{\circ} \mathrm{C}$ in a double-O cheese vat (Kusel Equipment Co., Watertown, WI). Milk was then warmed to $31^{\circ} \mathrm{C}$ before culture addition. Three replicates of the following 2 treatments were used: (1) EPS-positive (EPS+) Cheddar cheese made using the EPS-producing starter culture, and (2) EPS-negative (EPS-) Cheddar cheese made using the EPS nonproducing starter culture. Cultures were added to milk at $2 \%$ (wt/wt). After $15 \mathrm{~min}$ of ripening, in both EPS- and EPS+ treatments, the $\mathrm{pH}$ value was recorded and chymosin (Chymax, Chr. Hansen) was added at a rate of $8.4 \mathrm{~mL} / 100 \mathrm{~kg}$ of milk. Milk coagulated in 30 to $35 \mathrm{~min}$. Circular motion and $0.95-\mathrm{cm}$ cheese knifes were used for cutting, and curd was left undisturbed to heal for $10 \mathrm{~min}$. Two different cooking profiles were used to obtain similar chemical composition in both treatments. In the EPS+ Cheddar cheese, a constant temperature increase from 31 to $34^{\circ} \mathrm{C}$ in 15 min was followed by an increase from 34 to $39^{\circ} \mathrm{C}$ in 15 min. The curd was then held at $39^{\circ} \mathrm{C}$ for $30 \mathrm{~min}$. In the EPS- Cheddar cheese, a constant temperature increase from 31 to $35^{\circ} \mathrm{C}$ in 15 min was followed by holding at $35^{\circ} \mathrm{C}$ for $15 \mathrm{~min}$. Whey was drained when $\mathrm{pH}$ reached 6.3 to 6.35 . The curd was cheddared until a $\mathrm{pH}$ value of 5.4 to 5.45 was reached, and was then milled. Foodgrade salt at $0.8 \%$ by weight of curd was added in 2 equal applications over $10 \mathrm{~min}$. The curd was hooped in rectangular molds and pressed for $18 \mathrm{~h}$ at $4.2 \mathrm{~kg} / \mathrm{cm}^{2}$ pressure (AFVS-Spec, Kusel Equipment Co.). Cheeses were vacuum-sealed and kept at $6^{\circ} \mathrm{C}$. At $21 \mathrm{~d}$ of ripening, samples were drawn for texture analysis using borer size 15. Cheeses were shredded and samples were taken for chemical analyses. Cheeses were kept frozen until used for PCF manufacture.

\section{PCF Formulation and Manufacture}

Three replicates of PCF were made from each of the EPS- and EPS+ Cheddar cheeses that were previously shredded and frozen. Other ingredients used were low-heat NFDM (Associated Milk Producers Inc., New Ulm, MN), salt whey, unsalted butter (Land O' Lakes Inc., Arden Hills, MN), trisodium citrate (Yixing-Union 
Biochemical Co. Ltd., Yixing City, Jiangsu, China), salt, and water (Table 4). Techwizard, an Excel-based formulation software program (Metzger, 2003) provided by Owl Software (Lancaster, PA), was used to develop the PCF formulations. One of the factors that determines PCF properties is the amount of intact casein in natural cheese (Zehren and Nusbaum, 2000; Kapoor et al., 2007). Hence, the natural cheese level in the PCF was determined, based on the protein content, to give similar cheese protein in all formulations. In addition, salt whey was maintained at a level not to cause lactose crystallization (Thomas, 1973; Harper, 1992). A commercial 5 series, bowl lift stand mixer (KitchenAid, St. Joseph, MI) was used to blend the ingredients for 15 min at speed 6 . The bowl was covered with aluminum foil to prevent evaporation and contamination. The PCF was made using a rapid visco analyzer (RVA; Newport Scientific, Warriewood, NSW, Australia) following the method described by Kapoor et al. (2004). Approximately $25 \mathrm{~g}$ of the blend was transferred into aluminum vials designed for the RVA, and $0.6 \mathrm{~g}$ of distilled water was added to compensate for the moisture losses during manufacture. The PCF was cooked at $95^{\circ} \mathrm{C}$ with agitation speeds of $1,000 \mathrm{rpm}$ for 2 min followed by $160 \mathrm{rpm}$ for $1 \mathrm{~min}$, and then transferred into copper cylinders $(20 \mathrm{~mm}$ diameter $\times 30 \mathrm{~mm}$ height $)$. The copper cylinders were sealed with plastic foil and stored at $4^{\circ} \mathrm{C}$.

\section{Chemical Analysis of Cheese}

Cheddar and process cheeses were analyzed for moisture by drying 2 to $3 \mathrm{~g}$ of cheese at $100^{\circ} \mathrm{C}$ for $24 \mathrm{~h}$ in a forced draft oven (Fisher Scientific, Pittsburgh, PA), fat by Mojonnier (method 933.05; AOAC, 2006), salt by chloride analyzer (model 926, Nelson Jameson Inc., Marshfield, WI), and total protein by Kjeldahl block digester method (Hooi et al., 2004). The $\mathrm{pH}$ was measured using an Accumet gel-filled glass electrode with spear tip (Fisher Scientific) and Education $\mathrm{pH}$ meter (Fisher Scientific) in slurry prepared by macerating 20 $\mathrm{g}$ of shredded cheese in $20 \mathrm{~g}$ of distilled water at $40^{\circ} \mathrm{C}$ (Awad et al., 2005).

\section{Proteolysis of Cheddar Cheese}

Water-soluble nitrogen (WSN) and TCA-soluble nitrogen (TCA-SN) were determined at $21 \mathrm{~d}$ of Cheddar cheese ripening by the method described by Ardö (1999). Grated cheese samples in duplicate (30 g) were blended with $150 \mathrm{~mL}$ of distilled water $\left(40^{\circ} \mathrm{C}\right)$ and homogenized using a stomacher (Seward Stomacher Circulator 400, Norfolk, UK) for 5 min at $230 \mathrm{rpm}$. The homogenate was held for $1 \mathrm{~h}$ at $40^{\circ} \mathrm{C}$ and centrifuged for $30 \mathrm{~min}$ at $3,000 \times g$ (Sorvall RC-2 Superspeed Refrigerated Centrifuge; DuPont Co., Wilmington, DE); the supernatant was filtered through glass wool. For WSN determination, $5 \mathrm{~mL}$ of the filtrate was analyzed in duplicate for $\mathrm{N}$ content using the Kjeldahl block digester method (Hooi et al., 2004). For determination of the TCA-SN fraction, $25 \mathrm{~mL}$ of $24 \%$ TCA solution was mixed with $25 \mathrm{~mL}$ of the filtrate. The suspension was held at room temperature for at least $2 \mathrm{~h}$, and then filtered through Whatman No. 40 filter paper (Whatman, Middlesex, UK), and a 10-mL portion of the nitrogencontaining filtrate was analyzed.

\section{Texture Profile Analysis of Cheese}

Brass cork borer no.15 and a marble cheese slicing board (CheeseSlicing LLC, Sheboygan, WI) were used to prepare $20-\times 20-\mathrm{mm}$ cylindrical Cheddar cheese samples. The same size samples for the PCF were taken from the previously stored copper cylinders. Samples were wrapped using plastic foil and stored in sealed plastic bags to prevent dehydration. Before analysis, samples were kept at $20^{\circ} \mathrm{C}$ for $1 \mathrm{~h}$. Two-bite compression was performed using the TA.XT.plus texture analyzer (Texture Technologies Corp., Scarsdale, NY) with a $50-\mathrm{kg}$ load cell. The crosshead speed was 50 $\mathrm{mm} / \mathrm{min}$ and the compression ratio was $25 \%$ of the original height of the sample. Hardness, cohesiveness, gumminess, chewiness, springiness, and adhesiveness were determined at all ripening periods for Cheddar cheese and the corresponding PCF. The calculations were made using the texture profile curve as described by Bourne (1978).

\section{Meltability of PCF}

Meltability of PCF was determined using the modified Schreiber test (Muthukumarappan et al., 1999). Three discs, measuring $29 \mathrm{~mm}$ in diameter and $7 \mathrm{~mm}$ in height and approximately $5 \mathrm{~g}$, were randomly chosen from PCF for each test, wrapped in plastic foil to prevent dehydration, and kept at refrigeration temperature until analyzed (within $2 \mathrm{~h}$ of slicing). Cheeses were placed on $0.9-\mathrm{mm}$-thick aluminum plates $(10 \times 10 \mathrm{~cm})$ and heated in a forced-air convection oven (Gallenkamp Plus Oven, Weiss-Gallenkamp, Loughborough, UK) at $110^{\circ} \mathrm{C}$ for $5 \mathrm{~min}$. Samples were cooled at room temperature for $5 \mathrm{~min}$, and the area of the melted PCF was measured using a computer imaging system. The system consisted of a CCD coral video camera module (Sony, New York, NY), HLImage ++98 computer software (Western Vision Software, East Layton, UT), and 
a digitizer. The area of the sample after heat exposure was reported in millimeters squared and compared with the original area.

\section{Sensory Evaluation}

Sensory evaluation was conducted using the triangle test (ASTM, 2004). The method covers a procedure for determination of perceptible sensory difference between samples of 2 products, whether it is a single or several attributes. Analyzing the sensory data for statistical significance was done by comparison to data given in the test procedure instructions. The number of panelists ranged from 26 to 32 for each sensory test. Samples were presented in a random order and assigned 3-digit numbers as product codes to keep products anonymous. The statistical parameters used to calculate the difference between samples were taken from the standard test method for triangle test sensory analysis. Because the objective was to determine if the 2 products ( $\mathrm{PCF}$ containing salt whey and PCF control) were sufficiently similar, the value selected for $\beta$ risk was smaller than the value selected for $\alpha$ risk, and the value of $p_{\mathrm{d}}$ was selected to define "sufficiently similar" or "no significant difference." In this case, $\alpha$ risk, $\beta$ risk, and $p_{\mathrm{d}}$ values taken for statistical analysis were as follows: $\alpha \leq$ $0.05, \beta \leq 0.05$, and $p_{\mathrm{d}}=50 \%$. The minimum number of correct responses required for significance, for the corresponding number of assessors was calculated using the following formula:

Minimum number of responses $(\mathrm{x})=$ nearest whole number $>\mathrm{x}=n / 3+\mathrm{z}[\sqrt{ }(2 n / 9)]$,

where $\mathrm{z}=1.64$ at $\alpha=0.05$, and $n$ is the total number of assessors.

\section{Statistical Analyses}

The obtained data were analyzed by ANOVA using the General Linear Model procedure of SAS software (SAS Institute, 1999). The Scheffé multiple range test was used to compare means. Differences were considered significant at $P \leq 0.05$.

\section{RESULTS AND DISCUSSION}

\section{Composition and $\mathrm{pH}$ of Cheddar Cheese}

The chemical composition and $\mathrm{pH}$ of 3 -wk-old Cheddar cheese are given in Table 1 . The modified cheese making protocol in the EPS- cheese increased the moisture content to levels similar to those in the EPS+
Table 1. Chemical composition and $\mathrm{pH}( \pm \mathrm{SE})$ of 3-wk-old Cheddar cheese $^{1}$

\begin{tabular}{lccc}
\hline & \multicolumn{2}{c}{ Treatment $^{2}$} & \\
\cline { 2 - 3 } Item & EPS- & EPS+ & SEM \\
\hline Moisture (\%) & $41.83^{\mathrm{a}}$ & $41.53^{\mathrm{a}}$ & 0.31 \\
Fat (\%) & $30.92^{\mathrm{a}}$ & $30.77^{\mathrm{a}}$ & 0.23 \\
Protein (\%) & $21.23^{\mathrm{a}}$ & $20.90^{\mathrm{a}}$ & 0.16 \\
Salt (\%) & $0.60^{\mathrm{a}}$ & $0.61^{\mathrm{a}}$ & $<0.01$ \\
pH & $4.82 \pm 0.03$ & $4.94 \pm 0.03$ & $<0.01$ \\
\hline
\end{tabular}

${ }^{a}$ Means in the same row without common superscripts are significantly different $(P \leq 0.05)$.

${ }^{1}$ Mean of 3 replicates.

${ }^{2}$ EPS $-=$ control cheese EPS $+=$ exopolysaccharide (EPS)-positive cheese.

cheese. This was achieved by reducing cooking time and temperature. The moisture in Cheddar cheese was in the range of 41 to $42 \%$, which is higher than the legal limit (39\%). However, the intent was to use this cheese as an ingredient in making process cheese. We observed no significant differences $(P \geq 0.05)$ in moisture, fat, protein, and salt contents between the EPS- and EPS+ Cheddar cheeses. However, small differences in $\mathrm{pH}$ were seen between the 2 cheeses. Whey draining $\mathrm{pH}$, moisture content, and salting rate are factors influencing final $\mathrm{pH}$ of cheese. These parameters were maintained constant in both EPS- and EPS+ cheeses.

\section{Proteolysis of 3-wk-Old Cheddar Cheese}

Proteolysis plays a major role in Cheddar cheese texture development, which is reflected in process cheese characteristics (Kapoor and Metzger, 2008). Table 2 shows levels of WSN in Cheddar cheese: WSN did not differ significantly $(P \geq 0.05)$ in between EPS- and EPS + Cheddar cheeses. Trichloroacetic acid-soluble N is an indication of secondary breakdown of large peptides. This breakdown is mainly a result of chymosin activity and starter lactic acid bacteria peptidases (Lawrence et al., 1987). Table 2 shows that EPSCheddar cheese had slightly higher $(P \leq 0.05)$ TCASN levels than EPS+ cheeses, which was due to faster secondary proteolysis in the former cheese. Pastorino et al. (2003) described secondary proteolysis as the main factor responsible for flavor but not texture development in cheese.

\section{Textural Characteristics of Cheddar Cheese}

Hardness is defined as the force required to achieve given deformation. Hardness values of the EPS - and EPS + Cheddar cheeses at 3 wk of ripening are given in Table 3. The EPS- Cheddar cheese was harder than the 
Table 2. Proteolysis of 3-wk-old Cheddar cheese ${ }^{1}$

\begin{tabular}{lrrr}
\hline & \multicolumn{2}{c}{ Treatment $^{2}$} & \\
\cline { 2 - 3 } Item & EPS - & EPS + & SEM \\
\hline Water-soluble N (\% of total N) & $10.60^{\mathrm{a}}$ & $10.08^{\mathrm{a}}$ & 0.22 \\
TCA-soluble N (\% of total N) & $6.58^{\mathrm{a}}$ & $5.63^{\mathrm{b}}$ & 0.20 \\
\hline
\end{tabular}

${ }^{\mathrm{a}, \mathrm{b}}$ Means in the same row without common superscripts are significantly different $(P \leq 0.05)$.

${ }^{1}$ Mean of 3 replicates.

${ }^{2} \mathrm{EPS}-=$ control cheese; EPS $+=$ exopolysaccharide (EPS)-positive cheese.

EPS + cheese $(P \leq 0.05)$. Exopolysaccharides interfere with protein-protein interactions, leading to reduced firmness (Hassan, 2008). Adhesiveness is defined as the work required to pull cheese from the surface (Bourne, 1978). It increases with the increased ability of proteins to bind water. Adhesiveness did not differ significantly between the EPS+ and EPS- Cheddar cheeses $(P \geq$ $0.05)$, as shown in Table 3 . This finding was not consistent with the previous findings of Awad et al. (2005). In their study, Awad et al. (2005) found that reduced-fat Cheddar cheeses made with EPS-producing cultures had higher adhesiveness than those made without EPS. However, this higher adhesiveness was associated with higher moisture levels in the EPS+ cheese, which could explain the contradictory data between the 2 studies. Springiness is the height recovered by cheese sample during the time between second and first bite (Bourne, 1978). At $3 \mathrm{wk}$, EPS- Cheddar cheese was springier than EPS+ cheese $(P \leq 0.05)$. This indicated that the protein network in the EPS- cheese was more compact than that in the EPS+ cheese (Hassan, 2008). Cohesiveness is the ratio between the area obtained from second and first compression curves (Bourne, 1978). Table 3 shows that although the EPS+ and EPSCheddar cheeses were significantly different $(P \leq 0.05)$, differences in cohesiveness were very small. Agrawal and Hassan (2008) also reported that cohesiveness at 1 mo was similar in reduced-fat cheeses with or without EPS. At 3 wk of ripening, EPS + Cheddar cheese was less gummy than EPS- cheese $(P \leq 0.05)$. This was expected as hardness increases gumminess in cheese. Table 3 also shows that EPS+ Cheddar cheese was less chewy than the EPS - cheese $(P \leq 0.05)$. In addition, EPS + Cheddar cheese was more resilient than EPScheese $(P \leq 0.05)$.

The chemical composition of cheese and level of proteolysis are important factors determining its textural properties (Kapoor and Metzger, 2008). Because EPS+ and EPS- cheeses did not differ in composition, differences in the textural characteristics could be related to the presence of EPS. Differences in texture were previously reported between EPS+ and EPS- cheeses (Awad et al., 2005; Hassan and Awad, 2005; Dabour et al., 2006). However, this is the first study to compare EPS+ and EPS - cheeses containing the same moisture level.

\section{Chemical Composition and $\mathrm{pH}$ of PCF}

The ingredients used in PCF formulation are given in Table 4 . The levels of cheese protein and emulsifying salts were standardized in all formulations. The network in PCF is formed from the base cheese protein. The characteristics of the base cheese protein network determine how easily it disaggregates and creates an emulsion. The similar chemical composition in base EPSand EPS + Cheddar cheeses allowed the use of similar amounts of cheese $(\sim 63 \%)$ and salt whey $(\sim 12.5 \%)$ in the control and treatment cheeses. Cheddar cheese protein represented $13.10 \pm 0.10 \%$ of the total formula in EPS - PCF and $13.32 \pm 0.09 \%$ in the EPS + PCF. The chemical composition did not differ $(P \geq 0.05)$ between EPS - and EPS+ PCF (Table 5), although there was a 0.1-unit difference in the $\mathrm{pH}$ value. This was expected because EPS- Cheddar cheese had lower $\mathrm{pH}$ values than did the EPS+ cheese (Table 1), and no $\mathrm{pH}$ adjustment was made during PCF manufacture.

\section{Textural Characteristics and Meltability of PCF}

Table 6 shows the textural properties of PCF made from EPS+ and EPS- Cheddar cheeses. The EPS+ PCF had lower hardness, springiness, adhesiveness, and cohesiveness values than the EPS - cheese $(P \leq 0.05)$. It was also less gummy and chewy $(P \leq 0.05)$. Table 3 and Table 6 indicate the relationship between textural characteristics of Cheddar cheese and corresponding PCF. Such a relationship was not found by Hassan and

Table 3. Texture profile analysis of 3 -wk-old Cheddar cheese ${ }^{1}$

\begin{tabular}{|c|c|c|c|}
\hline \multirow[b]{2}{*}{ Item } & \multicolumn{2}{|c|}{ Treatment $^{2}$} & \multirow[b]{2}{*}{ SEM } \\
\hline & EPS- & EPS+ & \\
\hline Hardness (N) & $27.86^{\mathrm{a}}$ & $14.6^{\mathrm{b}}$ & 0.6 \\
\hline Adhesiveness $(\mathrm{J})$ & $88.78^{\mathrm{a}}$ & $104.53^{\mathrm{a}}$ & 19.75 \\
\hline Springiness (mm) & $0.81^{\mathrm{a}}$ & $0.78^{\mathrm{b}}$ & 0.008 \\
\hline Cohesiveness (-) & $0.83^{\mathrm{a}}$ & $0.82^{\mathrm{b}}$ & 0.007 \\
\hline Gumminess (N) & $2,162.41^{\mathrm{a}}$ & $1,191.35^{\mathrm{b}}$ & 48.66 \\
\hline Chewiness $(\mathrm{J})$ & $1,759.45^{\mathrm{a}}$ & $928.6^{\mathrm{b}}$ & 48.9 \\
\hline Resilience $(-)$ & $0.46^{\mathrm{b}}$ & $0.52^{\mathrm{a}}$ & 0.01 \\
\hline \multicolumn{4}{|c|}{$\begin{array}{l}\text { a,b Means in the same row without common superscripts are signifi- } \\
\text { cantly different }(P \leq 0.05) \text {. } \\
{ }^{1} \text { Mean of } 3 \text { replicates. } \\
{ }^{2} \text { EPS- = control cheese; EPS }+=\text { exopolysaccharide (EPS)-positive } \\
\text { cheese. }\end{array}$} \\
\hline
\end{tabular}


Table 4. Ingredients used in formulation of process cheese food ${ }^{1}$

\begin{tabular}{|c|c|c|}
\hline \multirow[b]{2}{*}{ Ingredient (\%) } & \multicolumn{2}{|c|}{ Treatment $^{2}$} \\
\hline & EPS- & EPS+ \\
\hline Cheese & 62.72 & 63.61 \\
\hline Salt whey & 12.53 & 12.33 \\
\hline $\mathrm{NFDM}^{3}$ & 12.58 & 12.74 \\
\hline Butter & 4.64 & 3.78 \\
\hline Water & 4.56 & 4.55 \\
\hline Emulsifying salts & 2.5 & 2.5 \\
\hline $\mathrm{NaCl}$ & 0.47 & 0.49 \\
\hline Cheese protein ${ }^{4}$ & 13.10 & 13.32 \\
\hline
\end{tabular}

${ }^{1}$ Mean of 3 replicates.

${ }^{2}$ EPS $-=$ control cheese EPS $+=$ exopolysaccharide (EPS)-positive cheese.

${ }^{3}$ Associated Milk Producers Inc., new Ulm, MN.

${ }^{4}$ Protein in process cheese food coming from Cheddar cheese.

Awad (2005), who manufactured PCF using different equipment from that used in this study, which might have influenced functionality of EPS. In addition, unlike in this study, the chemical composition differed between their EPS-negative and EPS-positive base cheeses. During PCF manufacture, EPS are exposed to shear and heat that can change their structure and functional properties. Exopolysaccharides act as nuclei for formation of large pores in base cheese, which reduces cheese rigidity (Hassan, 2008). Although the microstructure of base cheese collapses during cooking and shearing, the interference of EPS with protein-protein interactions may improve its melting. Tables 3 and 6 also show that the differences in textural properties between the EPS+ and EPS- Cheddar cheeses are greater than those in the corresponding process cheeses. In Cheddar cheese, EPS reduced hardness, gumminess, and chewiness by almost $50 \%$. Table 6 , however, shows only about $20 \%$ reductions in these parameters in the EPS+ PCF. This may be due to reduced functionality of EPS because of the heat treatment and shearing during process cheese cooking.

Meltability is a very important property of PCF. It determines possible applications of process cheese as a food ingredient (Kapoor and Metzger, 2008). Process cheese food containing EPS had higher $(P \leq 0.05)$ meltability than the control cheese. Similar results were reported by Awad et al. (2005). Even though they were heat treated during PCF manufacture, EPS could still interact with the protein and affect the newly formed network. The melting properties of the PCF are in direct correlation with its textural properties, especially cohesiveness (Harvey et al., 1982). The PCF containing EPS was less cohesive than the control cheese, thus higher meltability was expected. Cheese cohesiveness reflects the strength of the protein-protein interactions.
Table 5. Chemical composition and $\mathrm{pH}( \pm \mathrm{SE})$ of process cheese food made from 3 -wk-old Cheddar cheese ${ }^{1}$

\begin{tabular}{lccc}
\hline & \multicolumn{2}{c}{ Treatment $^{2}$} \\
\cline { 2 - 3 } Item & EPS- & EPS+ & SEM \\
\hline Moisture (\%) & $43.42^{\mathrm{a}}$ & $43.15^{\mathrm{a}}$ & 0.13 \\
Fat $(\%)$ & $23.77^{\mathrm{a}}$ & $23.66^{\mathrm{a}}$ & 0.10 \\
Protein $(\%)$ & $18.99^{\mathrm{a}}$ & $18.91^{\mathrm{a}}$ & 0.07 \\
Salt $(\%)$ & $2.10^{\mathrm{a}}$ & $2.12^{\mathrm{a}}$ & 0.01 \\
pH & $5.45 \pm 0.02$ & $5.55 \pm 0.03$ & 0.02 \\
\hline${ }^{\mathrm{a}}$ Means in the same row without common superscripts are significantly \\
different $(P \leq 0.05)$. & & \\
${ }^{1}$ Mean of 3 replicates. & & \\
${ }^{2}$ EPS- $=$ control cheese; & & \\
cheese.
\end{tabular}

In the EPS+ cheese, such interactions were disrupted by the presence of EPS.

\section{Emulsification Time and End Apparent Viscosity}

As described by Kapoor et al. (2004), during PCF manufacture in the RVA, a sudden increase in viscosity occurs at the beginning of cooking. This is followed by a decrease in viscosity, after which it remains constant. The sudden increase is an indicator of emulsion formation, and the time when it happens is referred to as emulsification time. At this point, the emulsifying salt has replaced enough calcium in the protein network and proteins have opened their structure and exposed their hydrophobic and hydrophilic sites (Kapoor and Metzger, 2005). The new protein sites are able to bind fat and water and create emulsions, which is the most important process in PCF manufacture. The emulsification time of EPS + PCF was significantly shorter than that in the EPS- PCF $(P \leq 0.05)$, as shown in Table 7 . This may indicate that EPS in Cheddar cheese bind to

Table 6. Texture profile analysis and meltability of process cheese food made from 3 -wk-old Cheddar cheese ${ }^{1}$

\begin{tabular}{|c|c|c|c|}
\hline \multirow[b]{2}{*}{ Item } & \multicolumn{2}{|c|}{ Treatment $^{2}$} & \multirow[b]{2}{*}{ SEM } \\
\hline & EPS- & EPS+ & \\
\hline Hardness (N) & $9.35^{\mathrm{a}}$ & $7.75^{\mathrm{b}}$ & 0.26 \\
\hline Adhesiveness $(\mathrm{J})$ & $22.04^{\mathrm{a}}$ & $10.07^{\mathrm{b}}$ & 3.55 \\
\hline Springiness (mm) & $0.77^{\mathrm{a}}$ & $0.73^{\mathrm{b}}$ & 0.008 \\
\hline Cohesiveness & $0.83^{\mathrm{a}}$ & $0.82^{\mathrm{b}}$ & 0.003 \\
\hline Gumminess $(\mathrm{N})$ & $787.83^{\mathrm{a}}$ & $646.72^{\mathrm{b}}$ & 22 \\
\hline Chewiness $(\mathrm{J})$ & $610.71^{\mathrm{a}}$ & $470.42^{\mathrm{b}}$ & 20.31 \\
\hline Meltability $\left(\mathrm{mm}^{2}\right)$ & $1,143.55^{\mathrm{b}}$ & $1,354.67^{\mathrm{a}}$ & 49.32 \\
\hline
\end{tabular}

${ }^{\mathrm{a}, \mathrm{b}}$ Means in the same row without common superscripts are significantly different $(P \leq 0.05)$.

${ }^{1}$ Mean of 3 replicates.

${ }^{2} \mathrm{EPS}-=$ control cheese; EPS $+=$ exopolysaccharide (EPS)-positive cheese. 
Table 7. Emulsification time and end viscosity of process cheese food made from 3-wk-old Cheddar cheese ${ }^{1}$

\begin{tabular}{lrrr}
\hline & \multicolumn{2}{c}{ Treatment $^{2}$} & \\
\cline { 2 - 3 } Item & \multicolumn{1}{c}{ EPS -} & \multicolumn{1}{c}{ EPS+ } & SEM \\
\hline Emulsification time $(\mathrm{s})$ & $33.7^{\mathrm{a}}$ & $26.64^{\mathrm{b}}$ & 0.65 \\
End apparent viscosity $(\mathrm{cP})$ & $1,908.78^{\mathrm{a}}$ & $2,110.84^{\mathrm{a}}$ & 34.19 \\
\hline
\end{tabular}

${ }^{\mathrm{a}, \mathrm{b}}$ Means in the same row without common superscripts are significantly different $(P \leq 0.05)$.

${ }^{1}$ Mean of 3 replicates.

${ }^{2}$ EPS $-=$ control cheese EPS $+=$ exopolysaccharide (EPS)-positive cheese.

protein and interfere with protein-protein bonds, which help the proteins disaggregate. Factors that influence emulsification are the textural properties of the base Cheddar cheese, the amount of emulsifying salts added, temperature during production, and auger speed and time. Because manufacturing parameters and formulations were kept constant, we conclude that the base cheese texture was the main factor determining the emulsification characteristics of the cheese. This confirms our hypothesis that it would be easier to emulsify young cheeses that contain EPS compared with young cheeses without EPS. Although EPS+ PCF had higher end apparent viscosity than EPS- PCF, which was expected due to the ability of EPS to crosslink proteins and increase viscosity of the serum phase (Hassan, 2008), the differences were not statistically significant $(P>0.05)$.

\section{Sensory Evaluation}

The aim of the sensory evaluation was to determine the effect of salt whey on process cheese flavor. For that purpose, 2 cheeses were made. In the first, salt whey was applied and in the second, salt and water were used. These PCF products were compared using the triangle test (ASTM, 2004). A minimum number of responses was set at 23 . The total number of responses was 88 and 32 responses were correct. This number was lower than the needed number of correct responses (45). Therefore, we concluded that the number of correct responses was not significant; that is, assessors could not recognize differences between the $2 \mathrm{PCF}$, and salt whey did not affect cheese flavor. Future work will focus on the effect of different salt levels, shear, and heat on functionality of different types of EPS in cheese.

\section{CONCLUSIONS}

This study compared the texture of EPS+ and EPS- Cheddar cheeses containing the same moisture levels. The difference in texture between these 2 cheeses indicated that the function of EPS is not limited to moisture retention. The study maximized the level of salt whey in process cheese by utilizing low salt, "easy to melt," young EPS+ Cheddar cheese. Process cheese food containing up to $13 \%$ salt whey with improved textural and melting properties could be made from this young Cheddar cheese.

\section{ACKNOWLEDGMENTS}

This research was supported by the US-Egypt Joint Science and Technology fund and the South Dakota Agricultural Experiment Station (Brookings). Additional funding was provided by the Midwest Dairy Foods Research Center.

\section{REFERENCES}

Agrawal, P., and A. N. Hassan. 2008. Characteristics of reduced fat Cheddar cheese made from ultrafiltered milk with an exopolysaccharide-producing culture. J. Dairy Res. 75:182-188.

AOAC. 2006. Official Methods of Analysis. 18th ed. Association of Official Analytical Chemists, Gaithersburg, MD.

Ardö, Y. 1999. Evaluating proteolysis by analyzing the $\mathrm{N}$ content of cheese fractions. Bull. Int. Dairy Fed. 337:4-9.

ASTM. 2004. ASTM E-1885-04: Standard test method for sensory analysis - Triangle test. ASTM Int., West Conshohocken, PA.

Awad, S., A. N. Hassan, and K. Muthukumarappan. 2005. Application of exopolysaccharide-producing cultures in reduced-fat Cheddar cheese: Texture and melting properties. J. Dairy Sci. 88:42044213.

Ayala-Hernández, I., A. H. Hassan, H. D. Goff, R. Mira de Orduña, and M. Corredig. 2008. Production, isolation and characterization of exopolysaccharides produced by Lactococcus lactis ssp. cremoris JFR1 and their interaction with milk proteins: Effect of $\mathrm{pH}$ and media composition. Int. Dairy J. 18:1109-1118.

Bourne, M. C. 1978. Texture profile analysis. Food Technol. 32:62$66 ., 72$.

Dabour, N., E. Kheadr, N. Benhamou, I. Fliss, and G. LaPointe. 2006. Improvement of texture and structure of reduced-fat Cheddar cheese by exopolysaccharide-producing lactococci. J. Dairy Sci. 89:95-110.

Gupta, V. K., and H. Reuter. 1992. Processed cheese foods with added whey protein concentrates. J. Dairy Sci. Technol. 72:201-212.

Harper, W. V. 1992. Lactose and lactose derivatives. Pages 326-328 in Whey and Lactose Processing. J. G. Zadow, ed. Elsevier Science Publishers Ltd., New York, NY.

Harvey, C. D., H. A. Morris, and R. Jenness. 1982. Relation between melting and textural properties of process Cheddar cheese. J. Dairy Sci. 65:2291-2295.

Hassan, A. N. 2008. ADSA foundation scholar award: Possibilities and challenges of exopolysaccharide-producing lactic cultures in dairy foods. J. Dairy Sci. 91:1282-1298.

Hassan, A. N., and S. Awad. 2005. Application of exopolysaccharideproducing cultures in reduced-fat Cheddar cheese: Cryo-scanning electron microscopy observations. J. Dairy Sci. 88:4214-4220.

Hassan, A. N., J. F. Frank, and M. Elsoda. 2003. Observation of bacterial exopolysaccharide in dairy products using cryo-scanning electron microscopy. Int. Dairy J. 13:755-762.

Hooi, R., D. M. Barbano, R. L. Bradley, D. Budde, M. Bulthaus, M. Chettiar, J. Lynch, and R. Reddy. 2004. Chemical and physical methods. Pages 363-536 in Standard Methods for the Examina- 
tion of Dairy Products. H. M. Wehr and J. F. Frank, ed. Am. Public Health Assoc., Washington, DC.

Kapoor, R., P. Lehtola, and L. E. Metzger. 2004. Comparison of pilotscale and rapid visco analyzer process cheese manufacture. J. Dairy Sci. 87:2813-2821.

Kapoor, R., and L. E. Metzger. 2004. Evaluation of salt whey as an ingredient in processed cheese. J. Dairy Sci. 87:1143-1150.

Kapoor, R., and L. E. Metzger. 2005. Small-scale manufacture of process cheese using a rapid visco analyzer. J. Dairy Sci. 88:33823391.

Kapoor, R., and L. E. Metzger. 2008. Process cheese: Scientific and technological aspects-A review. Compr. Rev. Food Sci. F 7:194214.

Kapoor, R., L. E. Metzger, A. C. Biswas, and K. Muthukumarappan. 2007. Effect of natural cheese characteristics on process cheese properties. J. Dairy Sci. 90:1625-1634.

Lawrence, R. C., L. K. Creamer, and J. Gilles. 1987. Texture development during cheese ripening. J. Dairy Sci. 70:1748-1760.

Metzger L. E. 2003. Nutrition labeling using a computer program. Pages 1-6 in Food Analysis Laboratory Manual. Kluwer Academic, New York, NY.

Muthukumarappan, K., Y. C. Wang, and S. Gunasekaran. 1999. Modified Schreiber test for evaluation of Mozzarella cheese meltability. J. Dairy Sci. 82:1068-1071.
Pastorino, A. J., C. L. Hansen, and D. J. McMahon. 2003. Effect of salt on structure-function relationships of cheese. J. Dairy Sci. 86:60-69.

Purna, S. K., A. Pollard, and L. E. Metzger. 2006. Effect of formulation and manufacturing parameters on process cheese food functionality-I. Trisodium citrate. J. Dairy Sci. 89:2386-2396.

Sanderson, W. B., A. P. Brady, G. F. Whitehead, I. J. Oldham, and I. P. Brockwell, inventors. 1996. Recycling salt solution in cheese processing and apparatus therefore. Murray Goulburn Co-Operative Co. Ltd., Australia, assignee. US Pat. No. 5,73,237.

SAS Institute. 1999. User's Guide: Statistics. Version 8 ed. SAS Inst. Inc., Cary, NC.

Sutherland, B. J. 1974. Control of salt absorption and whey drainage in Cheddar cheese manufacture. Aust. J. Dairy Technol. 29:86-93.

Thakur, M. K., J. R. Kirk, and T. I. Hedrick. 1975. Changes during ripening of unsalted Cheddar cheese. J. Dairy Sci. 58:175-180.

Thomas, M. A. 1973. The Manufacture of Processed Cheese-Scientific Principles. 1st ed. New South Wales Department of Agriculture, Richmond, NSW, Australia.

Zayed, G., and J. Winter. 1995. Batch and continuous production of lactic acid from salt whey using free and immobilized cultures of lactobacilli. Appl. Microbiol. Biotechnol. 44:362-366.

Zehren, V. L., and D. D. Nusbaum. 2000. Process Cheese. Cheese Reporter Publishing Co. Inc., Madison, WI. 